\title{
Anaphylaxis following the consumption of pumpkin seeds in a two-year-old child tolerant to its pulp - a case study and a minireview
}

\section{Julia Gawryjołek}

Nicolaus Copernicus University Faculty of Medicine: Uniwersytet Mikolaja Kopernika w Toruniu Collegium Medicum im Ludwika

Rydygiera w Bydgoszczy

\section{Hanna Ludwig}

Nicolaus Copernicus University Faculty of Medicine: Uniwersytet Mikolaja Kopernika w Toruniu Collegium Medicum im Ludwika

Rydygiera w Bydgoszczy

\section{Magdalena Żbikowska-Gotz}

Nicolaus Copernicus University Faculty of Medicine: Uniwersytet Mikolaja Kopernika w Toruniu Collegium Medicum im Ludwika Rydygiera w Bydgoszczy

\section{Zbigniew Bartuzi}

Nicolaus Copernicus University Faculty of Medicine: Uniwersytet Mikolaja Kopernika w Toruniu Collegium Medicum im Ludwika Rydygiera w Bydgoszczy

\section{Aneta Krogulska ( $\nabla$ aneta.krogulska@cm.umk.pl)}

Nicolaus Copernicus University in Torun: Uniwersytet Mikolaja Kopernika w Toruniu https://orcid.org/0000-0002-5280-1876

\section{Case report}

Keywords: pumpkin, seeds, pulp, food allergy, anaphylaxis, cross reactivity, child, case report

Posted Date: November 24th, 2020

DOI: https://doi.org/10.21203/rs.3.rs-112102/v1

License: (c) (i) This work is licensed under a Creative Commons Attribution 4.0 International License. Read Full License 


\section{Abstract}

Background

Pumpkin and its seeds are increasingly consumed by children for their potential health benefits. Each day, around $30 \%$ of teenagers consume nuts and seeds, including pumpkin seeds. However, there is some evidence that pumpkin seeds may exert allergenic effects and induce severe life-threatening anaphylaxis. Allergy for melon, cucumber, and zucchini, which belong to the same Cucurbitaceae family as pumpkin, are well known, opposite to pumpkin allergy. Few descriptions of allergic reactions associated with pumpkin have been published, especially in children. To date, three cases of pumpkin pulp and two seed cases have been reported among children. Our case report describes a case of pumpkin seed anaphylaxis in a child with good tolerance of pulp.

Case presentation

In the present study, a two-year-old child experienced anaphylaxis: generalized urticaria, swollen lips and increasing dyspnea following the consumption of pumpkin seeds. The history showed that although the child had been receiving elimination diet because of atopic dermatitis, the basic dietary element was pumpkin pulp. The skin-prick test was positive for pumpkin seeds $(5 \mathrm{~mm}$ ) but negative for pumpkin pulp $(1 \mathrm{~mm})$; allergen-specific lgE was $1.34 \mathrm{kUA} / \mathrm{L}$ for seed, and $0.37 \mathrm{kUA} / \mathrm{L}$ for pulp. The component resolved diagnosis found IgE to sesame seed, buckwheat and walnut (storage proteins). Based on these findings, severe anaphylactic reaction to pumpkin seeds was identified.

\section{Conclusions}

It is possible to develop pumpkin seed anaphylaxis in a child with a tolerance to pumpkin pulp. Pumpkin seeds allergens have not been well characterized. Homology between the amino acid sequences in storage proteins may indicate cross reactivity between different edible seeds and nuts.

\section{Background}

Like flax, poppy, sesame and sunflower seeds, pumpkin seeds are increasingly consumed for their potential health benefits. Their polyunsaturated fatty acid content bestows cardioprotective effects, and their phytosterols possess antioxidant, antiinflammatory and immunomodulatory properties [1]. Each day, around $32.4 \%$ of teenagers consume nuts and seeds, including pumpkin seeds [2,3]. However, there is some evidence that pumpkin seeds may exert allergenic effects and induce anaphylaxis. Few descriptions of allergic reactions associated with pumpkin have been published, especially in children [1,4-6].

\section{Case Presentation}

A two-year-old boy was referred to hospital for generalized urticaria, swollen lips and increasing dyspnea, observed around 10 minutes after eating pumpkin seeds for the first time in his life. Severe anaphylactic reaction was diagnosed.

Interview revealed a negative family history for allergies. The boy was born at $32 \mathrm{Hbd}$, body mass $1150 \mathrm{~g} /$ intrauterine hypotrophy; the pregnancy was the first one for the mother; delivery was by Caesarean section, Apgar score six points. From the age of two months, the child displayed loose stools and skin lesions characteristic of moderate atopic dermatitis (AD), with periodicallyobserved severe courses of AD. The child was breastfed up to five months of age (the mother was on a dairy-free and egg-free diet) followed by extensively hydrolysed formula based on whey protein at the end of breastfeeding. Due to persistent skin lesions (moderate-severe), an elimination diet was extended to the following months of life: wheat flour, soybean, carrot, apple, celery, pear, corn, broccoli and potato were excluded. At 15 months, the diet comprised whey hydrolysate, millet, rice, turkey, rabbit, watermelon, peach and bananas.

At around 16 months, the child entered the care to the Allergology outpatient clinic. It was proposed that the diet should be expanded to include potato, corn, broccoli and pumpkin pulp, which was introduced into the diet and well tolerated. From the age of 16 months, the pumpkin pulp become one of the most favourite meals; it was the basic dietary element and eaten daily in large 
quantities. Until the age of two years, apart from the observed exacerbations of $A D$, no other symptoms were observed. The child had been receiving topical treatments and elimination diets.

At the age of 2.5 years, while at home, the child experienced a sudden episode of anaphylaxis within 10 minutes of consuming pumpkin seeds shelled by his mother. Generalized urticaria, lip swelling and dyspnoea were observed. Adrenaline, systemic glucocorticosteroids, salbutamol and antihistamines were administered at a nearby hospital, and the symptoms regressed. A pumpkin seed elimination diet was initiated. After the incident, the child was referred to our Clinic (the Department of Paediatrics, Allergology and Gastroenterology) for diagnosis. During his stay in the clinic, the only deviation from the norm during physical examination was the presence of mild symptoms of AD (Scorad 20 points). The skin-prick test (SPT) based on the prick-by-prick method was positive for raw pumpkin seeds $(5 \mathrm{~mm})$ but negative for roasted pumpkin seed $(2 \mathrm{~mm})$ and pumpkin pulp $(1 \mathrm{~mm})$; total IgE was $111.8 \mathrm{kU} / \mathrm{L}$, allergen-specific $\lg \mathrm{E}$ (aslgE) was $1.34 \mathrm{kUA} / \mathrm{L}$ for seed, and $0.37 \mathrm{kUA} / \mathrm{L}$ for pulp. In addition, aslgE against cow milk (20 kUA/L), egg white $(6.3 \mathrm{kUA} / \mathrm{L})$, sesame $(0.78 \mathrm{kUA} / \mathrm{L})$ and hazelnut $(2.0 \mathrm{kUA} / \mathrm{L})$ were identified. The component resolved diagnosis (CRD) found medium to high level IgE to cow's milk protein, egg white, sesame seed and buckwheat (ISAC test). Sensitization to inhalant allergens was also determined: the ISAC test revealed Der $\mathrm{p} 1$ (7.7 ISU-E), Der $\mathrm{f} 1$ (10 ISU-E), Phl p 1 (7.5 ISU-E). Alternaria alternata aslgE was present at serum concentrations of $0.72 \mathrm{kUA} / \mathrm{L}$ and birch pollen aslgE at $0.68 \mathrm{kUA} / \mathrm{I}$ (Table 1). 
Patient SPT, aslgE and CRD results.

\begin{tabular}{|c|c|c|c|c|c|c|c|}
\hline \multicolumn{8}{|c|}{ ALLERGY TEST } \\
\hline \multicolumn{2}{|l|}{ SPT* } & \multicolumn{2}{|l|}{$\operatorname{aslg} \mathrm{E}^{\wedge}$} & \multicolumn{4}{|l|}{ CRD" } \\
\hline $\begin{array}{l}\text { Allergen } \\
\text { extracts }\end{array}$ & $\begin{array}{l}\text { Diameter } \\
(\mathrm{mm})\end{array}$ & $\begin{array}{l}\text { Allergen } \\
\text { extracts }\end{array}$ & $\begin{array}{l}\text { Concentrations } \\
(\mathrm{kUA} / \mathrm{L})\end{array}$ & Allergens & & & $\begin{array}{l}\text { ISU-E } \\
\text { ISAC }\end{array}$ \\
\hline \multicolumn{8}{|c|}{ FOOD ALLERGENS } \\
\hline $\begin{array}{l}\text { Pumpkin } \\
\text { seed }\end{array}$ & 5 & $\begin{array}{l}\text { Pumpkin } \\
\text { seed }\end{array}$ & 1.34 & & & & \\
\hline \multirow{10}{*}{$\begin{array}{l}\text { Pumpkin } \\
\text { pulp }\end{array}$} & 1 & Pumpkin & 0,37 & & & & \\
\hline & & Cow milk & 20.0 & Cow milk & $\begin{array}{l}\text { Alpha- } \\
\text { lactalbumin }\end{array}$ & $\begin{array}{l}\text { Bos d } \\
4\end{array}$ & 6.4 \\
\hline & & Egg white & 6.3 & & Casein & $\begin{array}{l}\text { Bos d } \\
8\end{array}$ & 2.5 \\
\hline & & Egg yolk & 0.40 & & $\begin{array}{l}\text { Beta- } \\
\text { lactogobulin }\end{array}$ & $\begin{array}{l}\text { Bos d } \\
5\end{array}$ & 1.4 \\
\hline & & Sesame & 0.78 & Egg white & Ovalbumin & $\begin{array}{l}\text { Gal d } \\
2\end{array}$ & 5.1 \\
\hline & & Wheat flour & 0.48 & & $\begin{array}{l}\text { Conalbumin/ } \\
\text { Ovotransferrin }\end{array}$ & $\begin{array}{l}\text { Gal d } \\
3\end{array}$ & 1.8 \\
\hline & & Peanut & 0.44 & & Ovomucoid & $\begin{array}{l}\text { Gal d } \\
1\end{array}$ & 1.7 \\
\hline & & Hazelnut & 2.0 & Buckwheat & $2 S$ albumin & $\begin{array}{l}\text { Fag e } \\
2\end{array}$ & 7.0 \\
\hline & & & & Sesame & $2 S$ albumin & $\begin{array}{l}\text { Ses i } \\
1\end{array}$ & 2.3 \\
\hline & & & & Walnut & 7S globulin & $\begin{array}{l}\text { Jug } r \\
2\end{array}$ & 0.4 \\
\hline \multicolumn{8}{|c|}{ INHALANT ALLERGENS } \\
\hline & & $\begin{array}{l}\text { D. } \\
\text { pteronyssinus }\end{array}$ & 0.33 & $\begin{array}{l}\text { D. } \\
\text { pteronyssinus }\end{array}$ & & $\begin{array}{l}\text { Der } p \\
1\end{array}$ & 7.7 \\
\hline & & D. farinae & 0.26 & D. farinae & & $\underset{1}{\text { Der } \mathrm{f}}$ & 10 \\
\hline & & $\begin{array}{l}\text { Phleum } \\
\text { pratense }\end{array}$ & 0.16 & $\begin{array}{l}\text { Phleum } \\
\text { pratense }\end{array}$ & & $\begin{array}{l}\text { Phl } \\
\text { p1 }\end{array}$ & 7.5 \\
\hline \multicolumn{8}{|c|}{ *SPT - skin prick tests (using the prick by prick method); wheal diameter: positive control - $4 \mathrm{~mm}$; negative control - $1 \mathrm{~mm}$} \\
\hline \multicolumn{8}{|c|}{ ^aslgE - allergen-specyfic IgE antibodies (ImmunoCAP-FEIA, Sweden) (bold $\geq-0.7$ kUA/L, i.e. $\geq 2$ class) } \\
\hline
\end{tabular}

Based on the history, symptoms and results of the testing, anaphylactic reaction to pumpkin seeds was identified. A pumpkin seed elimination diet was recommended. In addition, it was planned to verify previous elimination diets and continue AD treatment. Currently, the child eats a standard diet apart from grains, peanuts, tree nuts, raw egg white and raw milk. It is planned 
to perform further oral food challenges and to gradually broaden the diet; however, the mother of the child has strong concerns and reservations in this regard.

During follow-up, allergic asthma was diagnosed at the age of three years: the asthma is mild and seasonal, but well controlled. At the age of five years, the child is sensitized to birch pollen (>100 kUA/L), gray alder pollen (1.9 kUA/L), rye pollen (0.96 kUA/L), timothy grass (0.48 kUA/L), D. pteronyssinus (30 kUA/L), D. farinae (15 kUA/L) and A. alternata $(3.1 \mathrm{kUA} / \mathrm{L})$. He receives medication during the allergy season i.e. spring (April/May) (montelukast and fluticasone $2 \times 125 \mu \mathrm{g}$ inhaled while walking). Exacerbations of asthma are also experienced after exercise. Since three years old, the AD has remained in remission, although it worsens around spring. On one occasion, a rash was observed on the skin following contact with raw milk. The anaphylactic reactions have not recurred.

\section{Discussion And Conclusions}

Pumpkin belongs to the Cucurbitaceae family, which comprises about 120 genera and 760 species of plants. Allergy for melon, cucumber, and zucchini are well known, opposite to pumpkin allergy (all Cucurbitaceae family) $[7,8]$. For pumpkins, the pulp, skin and seeds all elicit allergic responses [7]; however, individual case studies mainly report seed allergies (Table 2) [1, 4-7, 9-12]. Among children, three cases have been reported for pumpkin pulp and two for seeds $[1,4-6]$. 
Table 2

Pumpkin seed allergy - summary of published case reports.

\begin{tabular}{|c|c|c|c|c|c|c|c|c|c|c|c|}
\hline \multirow[t]{2}{*}{ References } & \multirow[t]{2}{*}{ Child } & \multirow[t]{2}{*}{ Adult } & \multicolumn{2}{|l|}{ Pumpkin } & \multirow[t]{2}{*}{ Symptoms } & \multirow[t]{2}{*}{ Atopy } & \multicolumn{2}{|l|}{ SPT } & \multicolumn{2}{|l|}{ slgE } & \multirow[t]{2}{*}{ OFC } \\
\hline & & & flesh & seeds & & & flesh & seeds & flesh & seeds & \\
\hline \multirow{2}{*}{$\begin{array}{l}\text { Chatain et al } \\
{[1]} \\
2017\end{array}$} & \multirow[t]{2}{*}{ 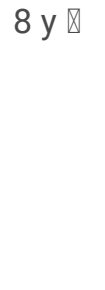 } & & & + & \multirow{2}{*}{$\begin{array}{l}\text { grade } 3 \\
\text { anaphylaxis } \\
\text { with deep } \\
\text { faintness, } \\
\text { vomiting, } \\
\text { facial and } \\
\text { pharyngeal } \\
\text { edema }\end{array}$} & \multirow[t]{2}{*}{+} & \multirow[t]{2}{*}{-} & \multirow[t]{2}{*}{+} & \multirow[t]{2}{*}{ - } & \multirow{2}{*}{$\begin{array}{l}3.75 \\
\mathrm{KU} / \mathrm{L}\end{array}$} & \\
\hline & & & & & & & & & & & \\
\hline $\begin{array}{l}\text { Caubet et al } \\
\text { [4] }\end{array}$ & \multirow{2}{*}{\multicolumn{2}{|c|}{$\begin{array}{l}11 \mathrm{y} \\
\square\end{array}$}} & & + & \multirow[t]{2}{*}{$\begin{array}{l}\text { urticaria, } \\
\text { angioedema } \\
\text { and dyspnea }\end{array}$} & \multirow[t]{2}{*}{+} & & \multirow[t]{2}{*}{-} & & & \multirow[t]{2}{*}{+} \\
\hline 2010 & & & & & & & & & & & \\
\hline \multirow{2}{*}{$\begin{array}{l}\text { Hagendorens } \\
\text { et al [5] } \\
2009\end{array}$} & \multirow[t]{2}{*}{$\begin{array}{l}2.5 \mathrm{y} \\
\square\end{array}$} & & \multirow[t]{2}{*}{ soup } & & \multirow{2}{*}{\multicolumn{2}{|c|}{$\begin{array}{l}\text { vomiting, } \\
\text { coughing, } \\
\text { dyspnea, } \\
\text { urticaria and } \\
\text { angioedema }\end{array}$}} & \multirow[t]{2}{*}{+} & & \multirow[t]{2}{*}{$\begin{array}{l}25.20 \\
\mathrm{kU} / \mathrm{L}\end{array}$} & & \\
\hline & & & & & & & & & & & \\
\hline \multirow{4}{*}{$\begin{array}{l}\text { La Shell et al } \\
\text { [6] } \\
2010\end{array}$} & $\begin{array}{l}18 y \\
{[}\end{array}$ & & \multirow{4}{*}{$\begin{array}{l}\text { cake } \\
\text { contact } \\
\text { with } \\
\text { pumpkin }\end{array}$} & & \multirow{4}{*}{$\begin{array}{l}\text { generalized } \\
\text { pruritus, } \\
\text { shortness of } \\
\text { breath, and } \\
\text { throat } \\
\text { tightness; } \\
\text { nasoocular } \\
\text { pruritus, } \\
\text { sneezing, } \\
\text { eyelid swelling, } \\
\text { and chest } \\
\text { tightness while } \\
\text { carving a } \\
\text { pumpkin }\end{array}$} & \multirow{4}{*}{$\begin{array}{l}+ \\
+\end{array}$} & \multirow[t]{4}{*}{+} & + & 33.50 & & \\
\hline & $8 y \otimes$ & & & & & & & & $\mathrm{kU} / \mathrm{L}$ & & \\
\hline & & & & & & & & & & & \\
\hline & & & & & & & & & & & \\
\hline $\begin{array}{l}\text { Figueredo et } \\
\text { al [7] }\end{array}$ & & 28 y $\nabla$ & soup & & $\begin{array}{l}\text { several } \\
\text { episodes of } \\
\text { itching }\end{array}$ & & + & & & & + \\
\hline 2000 & & & & & $\begin{array}{l}\text { of the mouth, } \\
\text { angioedema of } \\
\text { the lips and } \\
\text { face, } \\
\text { generalized } \\
\text { itching, }\end{array}$ & & & & & & \\
\hline & & & & & $\begin{array}{l}\text { and mild } \\
\text { dyspnea }\end{array}$ & & & & & & \\
\hline $\begin{array}{l}\text { Fritsch et al } \\
\text { [9] }\end{array}$ & & 49 y $\nabla$ & & + & $\begin{array}{l}\text { oropharyngeal } \\
\text { itching and }\end{array}$ & + & & + & & $\begin{array}{l}+(2 \\
\text { class })\end{array}$ & \\
\hline 1997 & & $29 y \nabla$ & & + & swelling, & + & & + & & +8 & \\
\hline & & $46 y \otimes$ & & + & & + & & - & & class) & \\
\hline & & & & & & & & & & $\begin{array}{l}+(2 \\
\text { class })\end{array}$ & \\
\hline
\end{tabular}




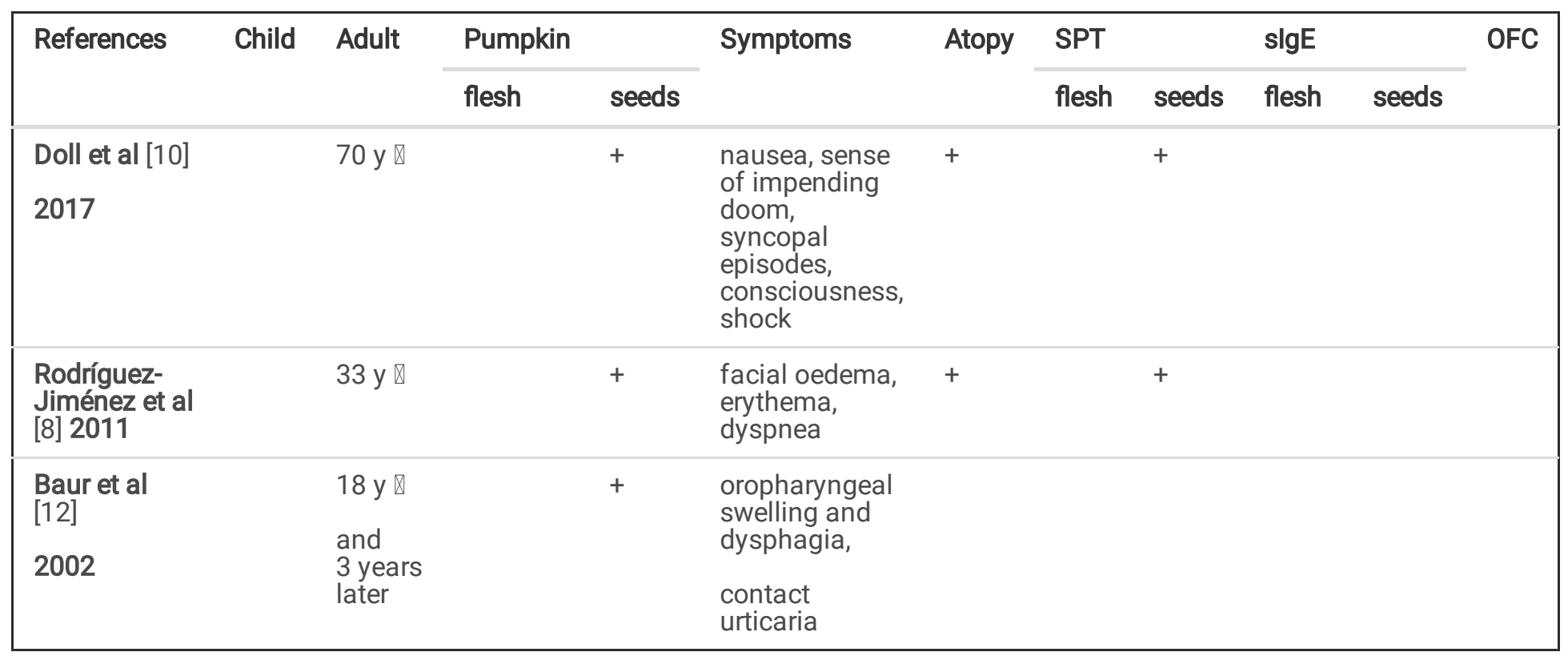

Our report is a valuable complement to previous studies in which children experienced anaphylaxis after ingestion of seeds, with good tolerance of pulp [1,4-6]. Another two children experienced anaphylaxis after consuming the pulp in the form of pumpkin soup or cake $[5,6]$.

Although pumpkin allergy (PA) usually develops following consumption, reports suggest the possibility of exposure through skin contact and/or inhalation of raw pumpkin or pumpkin seed allergens, e.g. while carving pumpkin $[6,9,13]$. Also, PA appears to be more common in males, especially atopic patients; our patient is a boy with co-existing AD and asthma.

Among adults, only one case with anaphylaxis to pumpkin flesh has been described, and six with anaphylaxis to pumpkin seeds (Table 2) [6, 12].

PA can range from mild oral symptoms to severe life-threatening anaphylaxis. Most reactions are mild, manifesting as only local symptoms in the mouth and throat [7]. However, some patients display vomiting, angioedema (face and throat), urticaria, erythema, dyspnoea, syncope and shock $[1,4,10,11]$. Pumpkin pulp allergy can also manifest as food protein induced enterocolitis syndrome [14].

Similar to our case, most previous patients displayed positive prick-by-prick ST for pumpkin seeds, and positive serum aslgE for pumpkin seeds. The high allergenic potential of pumpkin seeds means that allergy symptoms, including severe anaphylaxis, can occur at low aslgE levels. In addition, it is important to consider pumpkin seed allergy in patients with an unclear history of anaphylaxis, even following a negative SPT [4].

In our patient, the interview was unambiguous, i.e. symptoms appeared immediately after the consumption of pumpkin seeds shelled from pumpkin by the child's mother, and tests confirmed IgE sensitization. Hence, the food challenge test was abandoned.

Some patients with PA have cross sensitization to plants from the Rosaceae and Cucurbitaceae families and to pollen such as ragweed [6].

The development of pumpkin seed allergy is not precisely understood as the allergens have not been well characterized $[1,11]$. Immunoblotting has identified proteins with a molecular weight of $14 \mathrm{kDa}$, possibly a profilin homologue, and $12 \mathrm{kDa}$, possibly an LTP homologue, in the sera of patients with pumpkin seed allergy $[9,11]$. In the present patient, CRD did not identify aslgE for the cross-reactive panallergens LTP and profilin, which may indicate that other proteins are involved in the anaphylactic reactions, e.g. 2S albumin, 7S and 11S globulin; these are highly anaphylactogenic storage proteins present in the seeds of many plants, including sesame and sunflower [15]. 
Sensitization to cross-reacting allergens may contribute to exacerbations of food allergy; however, the testing performed at 2,5 years did not indicate the possibility of cross-reactivity to liable allergens. Only a very low concentration of slgE to birch pollen and a high level anti-Phl p 1 antibodies (the main allergen marker of sensitivity to various grasses such as Timothy grass) were found.

Co-factors may play a significant role in the development of anaphylactic reactions, including those associated with pumpkin seeds. While squash-dependent anaphylaxis has previously been observed in a child following exercise [16], the anaphylactic reaction observed in our patient was not accompanied by any additional factors which could enhance systemic reaction, such as exercise or medications.

High and medium aslgE levels were found for $2 \mathrm{~S}$ sesame seed and buckwheat albumin, suggesting their presence in pumpkin seeds. 2S albumin proteins are present in peanuts, some tree nuts and many seeds (including sunflower and sesame seeds), and due to their disulphide bonds and glycosylation, they can cause severe IgE-dependent allergic reactions [11, 15]. PA has been found to co-occur with allergies to sunflower, poppy, almond and hazelnut seeds $[1,11]$.

Anaphylaxis case reports show that symptoms may develop after eating roasted seeds, indicating high allergen thermostability $[1,4,10]$. The prick-by-prick test with roasted pumpkin seeds was negative in our subject. The negative test result rules out the possibility that storage proteins may play a role, due to their exceptional stability; however, it does not negate the potential role played by other protein allergens. In a similar way to peanuts, raw pumpkin seeds contain specific allergens, together with a suitable epitope composition, while roast seeds may possess proteins with different allergenicity: roasting may lead to the development of new epitopes, which are not recognised by the aslgE prepared for the raw pumpkin seeds. However, little data is available on this topic.

In addition, the activity of other potential allergens, such as LTP proteins and oleosins, which are also found in other seeds (e.g. peanuts, hazelnuts, sesame seed, soya and sunflower) should also be taken into consideration. LTP proteins show relatively low amino acid sequence homology with allergenic LTP proteins from other sources, and therefore may not give a positive result for other LTPs in the ISAC test. Both the oleosins and LTP demonstrate less resistance to thermal processes than storage proteins, which may be the cause of a negative prick-by-prick test result based on roast pumpkin seeds. It is not possible to rule out the possibility that these proteins may have played a role in the sensitisation of our patient. Therefore, it appears certain that these proteins present in raw pumpkin seed participated in the anaphylactic reaction in the described patient.

In our case report, aslgE was found for the walnut allergen Jug $\mathrm{r} 2-7 \mathrm{~S}$ globulin. The 7S and 11S globulin proteins are contained in the seeds of legumes (soybeans, peanuts), also in tree nuts and sesame seeds. Hazelnut allergen Cor a $911 \mathrm{~S}$ globulin aslgE has previously been identified in an eight-year-old boy with anaphylaxis after ingesting pumpkin seeds [1]. Homology between the amino acid sequences in storage proteins may indicate cross reactivity between different edible seeds, peanuts and tree nuts [15].

It is possible to develop pumpkin seed anaphylaxis in a child with a tolerance to pumpkin pulp. Pumpkin seeds allergens have not been well characterized. Homology between the amino acid sequences in storage proteins may indicate cross reactivity between different edible seeds and nuts. Our findings are of special value, particularly in children, considering the current trend toward health foods. Pumpkin, sesame, sunflower, linen and poppy seeds should be included in the standard diagnostic procedures for food allergy.

\section{Abbreviations}

$A D$ - atopic dermatitis

SPT - skin-prick test

aslgE - allergen-specific $\lg \mathrm{E}$

CRD - component resolved diagnosis

PA - pumpkin allergy 


\section{Declarations}

1. The study was approved by Ethical Committee of CM Bydgoszcz, NCU Torun, no KB 74/2020.

2. Consent for publication: yes.

3. Availability of data and materials: The datasets analysed during the current study are available from the corresponding author on reasonable request.

4. Competing interests: The authors declare that they have no competing interests.

5. Funding: No funding.

6. Authors' contributions: J.G., H.L. and A.K. equally contributed to the conception and design of the research; J.G., H.L., M.ŻG., Z.B. and A.K. contributed to the acquisition and analysis of the data; H.L., J.G. and A.K. contributed to the interpretation of the data; and H.L., J.G. and A.K. drafted the manuscript. All authors critically revised the manuscript, agree to be fully accountable for ensuring the integrity and accuracy of the work, and read and approved the final manuscript.

7. Acknowledgements: Not applicable.

\section{References}

1. Chatain C, Pin I, Pralong P, Jacquier JP, Leccia MT. Medicinal bioactivities and allergenic properties of pumpkin seeds: review upon pediatric food anaphylaxis case report. Eur Ann Allergy Clin Immunol. 2017; 49: 244-251.

2. Nielsen SJ, Herrick KA, Akinbami LJ, Ogden CL. Nut Consumption Among U.S. Youth, 2009-2012. NCHS Data Brief. 2016; 238: 1-8.

3. Patel A, Bahna SL. Hypersensitivities to sesame and other common edible seeds. Allergy. 2016; 71: 1405-13.

4. Caubet JC, Hofer MF, Eigenmann PA, Wassenberg J. Snack seeds allergy in children. Allergy. 2010; 65: 136-7.

5. Hagendorens MM, Carrette M, Bridts CH, Stevens WJ, Ebo DG. Allergy from giant pumpkin (Cucurbita maxima) is not a fairy tale. Allergy. 2009; 64: 1694-6.

6. La Shell MS, Otto HF, Whisman BA, Waibel KH, White AA, Calabria CW. Allergy to pumpkin and crossreactivity to pollens and other foods. Ann Allergy Asthma Immunol. 2010; 104: 178-80.

7. Figueredo E, Cuesta-Herranz J, Minguez A, Vidarte L, Pastor C, De las HM et al. Allergy to pumpkin and crossreactivity to other Cucurbitaceae fruits. J Allergy Clin Immunol 2000; 106: 402-403.

8. Reindl J, Anliker MD, Karamloo F, Vieths S, Wuthrich B. Allergy caused by ingestion of zucchini (Cucurbita pepo): characterization of allergens and cross-reactivity to pollen and other foods. J Allergy Clin Immunol 2000; 106: 379-385.

9. Fritsch R, Ebner H, Kraft D, Ebner C. Food allergy to pumpkin seed - characterization of allergens. Allergy. 1997; 52: 335-7.

10. Doll R, Johnson J, Peppers BP, Tcheurekdjian H, Hostoffer R. IgE-mediated anaphylactic shock caused by pumpkin seed in an adult. Ann Allergy Asthma Immunol. 2017; 118: 377-378.

11. Rodríguez-Jiménez B, Domínguez-Ortega J, Ledesma A, González-García JM, Kindelan-Recarte C. Food allergy to pumpkin seed. Allergol Immunopathol. 2010; 38: 50-1.

12. Baur X, Gahnz G. Allergy to pumpkin seed in the form of intolerance and Occupational con-tact urticaria: a case report. Dermatologie in Beruf und Umwelt. 2002; 50: 178-9.

13. Arochena L, Gámez C, del Pozo V, Fernández-Nieto M. Cutaneous allergy at the supermarket. J Investig Allergol Clin Immunol. 2012; 22: 441-2.

14. Ruffner MA, Finegold DN, MacGinnitie AJ. Infant with unusual food reactions. Acta Paediatr. 2011; 100: 1289, 1394-5.

15. Scala E, Villalta D, Meneguzzi G, Giani M, Asero R. Storage molecules from tree nuts, seeds and legumes: relationships and amino acid identity among homologue molecules. Eur Ann Allergy Clin Immunol. 2018; 50: 148-155. 
16. Kim SM, Yoo SH, Kim MK. A Case of Squash-dependent Exercise-induced Anaphylaxis. Korean J Asthma Allergy Clin Immunol. 2011; 31(2):140-3. 